\title{
Coronaviruses Detected in Brazilian Wild Birds Reveal Close Evolutionary Relationships with Beta- and Deltacoronaviruses Isolated From Mammals
}

\author{
Ricardo Durães-Carvalho ${ }^{1,4}$ (D) Leonardo C. Caserta $^{1} \cdot$ Ana C. S. Barnabé ${ }^{1} \cdot$ \\ Matheus C. Martini ${ }^{1}$ - Helena L. Ferreira ${ }^{3}$ - Paulo A. N. Felippe ${ }^{1}$. \\ Márcia B. Santos ${ }^{2} \cdot$ Clarice W. Arns ${ }^{1}$
}

Received: 21 June 2015/Accepted: 4 August 2015/Published online: 7 August 2015

(C) Springer Science+Business Media New York 2015

\begin{abstract}
This study showed that the most of the coronaviruses (CoVs) detected in Brazilian wild birds clustered with the mouse hepatitis virus A59 strain, belonging to the BetaCoV group. Furthermore, $\mathrm{CoV}$ detected in two different bird species, Amazona vinacea and Brotogeris tirica, clustered with a $\mathrm{CoV}$ isolated from Sparrow (SpaCoV HKU17) belonging to a monophyletic group related with the CoVs isolated from swines (PorCoV HKU15), both belonging to the Delta $\mathrm{CoV}$ genus, previously unreported in South America. Considering the risk of inter-species host switching and further adaptation to new hosts, detection in bird species of CoVs closely related to mammal CoVs should warn for the potential emergence of new threatening viruses.
\end{abstract}

Keywords Coronavirus - Betacoronavirus ·

Deltacoronavirus · Wild birds · Evolution

Coronaviruses (CoVs), belonging to the order Nidovirales, family Coronaviridae, and subfamily Coronavirinae, are grouped into the AlphaCoV, BetaCoV, GammaCoV, and DeltaCoV genera (Woo et al. 2011). Alpha- and BetaCoVs

Electronic supplementary material The online version of this article (doi:10.1007/s00239-015-9693-9) contains supplementary material, which is available to authorized users.

\footnotetext{
Ricardo Durães-Carvalho

rdcarval@gmail.com

University of Campinas (UNICAMP), Campinas, SP, Brazil

Federal University of Juiz de Fora, Minas Gerais, MG, Brazil

São Paulo University, Pirassununga, SP, Brazil

4 Present Address: Massachusetts Institute of Technology (MIT), Cambridge, MA, USA
}

infect or cause disease in mammals, while GammaCoV are almost exclusively found in birds, except for the $\mathrm{CoV}$ detected in beluga whale and bottlenose dolphin (Mihindukulasuriya et al. 2008; Woo et al. 2010). The fourth genus $($ Delta $\mathrm{CoV})$ was described recently and has already been identified in pigs and birds (Woo et al. 2011).

In this research, 368 cloacal and tracheal swabs from 33 bird species were collected in different regions belonging to the States of São Paulo (Bosque dos Jequitibás, Campinas-SP; Rio Claro-SP; Rehabilitation center [CRAS] Parque Ecológico do Tietê, São Paulo-SP) and Mato Grosso do Sul (CRAS Campo Grande-MS), Brazil. The viral RNA was extracted (QIAmp Viral RNA Mini kit, QIAGEN, Hilden, Germany), and the cDNA synthesis was performed following the manufacturer's protocol (Applied Biosystems, Foster City, USA).

A PanCoV PCR selective essay was performed targeting a 440 bp of RNA-dependent RNA polymerase (RdRp) gene (Chu et al. 2011). Nineteen samples (5.2\%) distributed in 11 bird species were positive for $\mathrm{CoV}$. The positive $\mathrm{CoV}$ species are as follows: Amazona vinacea, Ara ararauna, Asio clamator, Brotogeris tirica, Colaptes campestris, Columba livia, Coragyps atratus, Megascops choliba, Pitangus sulphuratus, Pyroderus scutatus, and Rupornis magnirostris (See Supplementary Table S1).

Different $\mathrm{CoV}$ sequences were used to represent the four $\mathrm{CoV}$ genera of the family Coronaviridae. Phylogenetic inference was reconstructed and implemented in FastTree 2.1.7 software (Price et al. 2010) using the MaximumLikelihood (ML) method with the General Time-Reversible (GTR) model of nucleotide evolution with 20 rates of gamma distribution and 1.000 Shimodaira-Hasegawalike (SH-like) values.

Our results showed that most of the samples clustered with the mouse hepatitis virus A59 strain (MHV A59) 


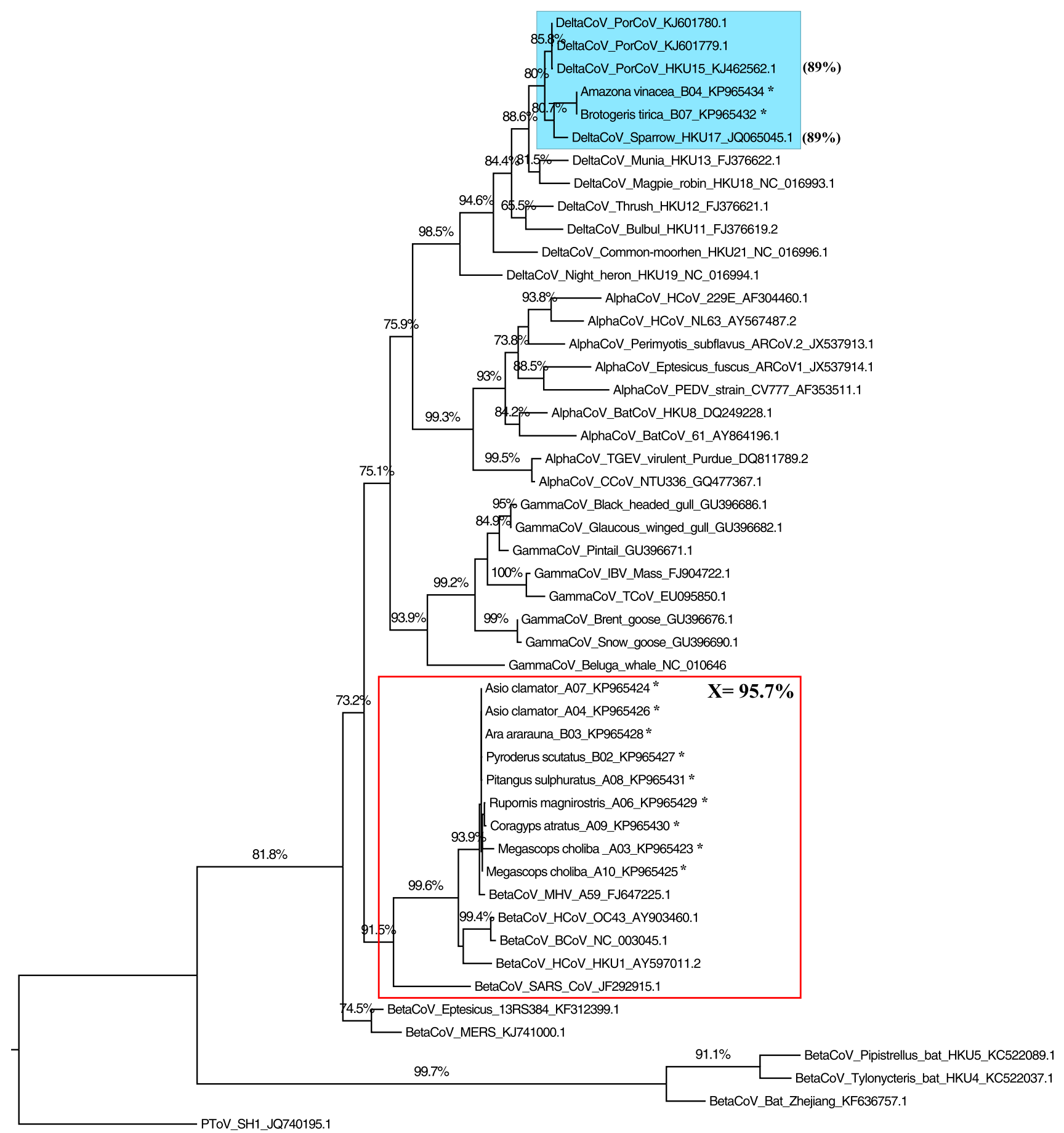

belonging to the Beta $\mathrm{CoV}$ group. Mice are the natural hosts of MHV A59, which is associated to hepatotropic and neurotropic diseases (Eriksson et al. 2008). Besides, two of our samples that were, respectively, detected in A. vinacea (Parrot-breasted-purple) and B. tirica (Plain Parakeet) clustered with $\mathrm{CoV}$ isolated from Sparrow (SpaCoV
HKU17) belonging to a monophyletic group related with the CoVs isolated from swines (PorCoV HKU15), both belonging to the Delta CoV genus (Fig. 1), previously unreported in South America. PorCoV HKU15 was detected in April 2014 in the USA (Wang et al. 2014), in 2015 , which was directly associated to play a key role in 
४Fig. 1 Molecular phylogenetic inference with Alpha-, Beta-, Gamma-, and DeltaCoV groups by ML method under GTR evolutionary model for the partial RdRp gene $(267 \mathrm{bp})$. The colors represent $\mathrm{CoVs}$ detected in wild birds grouped with BetaCoV (red) and DeltaCoV (highlighted in blue) groups. The asterisk represents the bird samples from which the DNA sequences were obtained. The number within parenthesis shows the nucleotide identities of PorCoV HKU15 and SpaCoV HKU17 (both DeltaCoVs) with the CoV detected in Amazona vinacea. The letter $X$ represents the arithmetic mean of nucleotide identities between the CoVs detected in the study and the MHV A59. The GenBank accession numbers of sequences deposited (from study) and retrieved from the database are shown in the tree. PorCoV porcine coronavirus; $\mathrm{HCoV}$ human coronavirus; $P E D V$ porcine epidemic diarrhea virus; $\mathrm{BatCoV}$ bat coronavirus; $T G E V$ transmissible gastroenteritis coronavirus; $\mathrm{CCoV}$ canine coronavirus; $I B V$ infectious bronchitis virus; $T C o V$ turkey coronavirus; $M H V$ mouse hepatitis virus; $B C o V$ bovine coronavirus; SARS severe acute respiratory syndrome; $M E R S$ middle east respiratory syndrome coronavirus; PToV (outgroup) porcine torovirus. The numbers above the branches represent the SH-like support values of 1000 replicates. Only values greater than or equal to $70 \%$ are presented. Online version in color

diarrheic disease in swine; no treatment or vaccines are currently available (Hu et al. 2015; Ma et al. 2015).

Finally, we highlighted in this study the evolutionary proximity of CoVs detected in wild birds with Beta- and DeltaCoVs, both isolated from mammal and involved in the pathogenicity of their hosts. We believe that these findings may be useful for the understanding of CoVs' evolutionary dynamics. Considering the risk of inter-species host switching and further adaptation to new hosts, detection in bird species of CoVs closely related to mammal CoVs should warn for the potential emergence of new threatening viruses.

Acknowledgments We thank the teams from Bosque dos Jequitibás; Rio Claro-SP; CRAS Parque Ecológico do Tietê-SP; and Campo Grande-MS. This work was supported by Fundação de Amparo à Pesquisa do Estado de São Paulo (FAPESP), Grants 2013/03922-6 and 2011/50919-5.

\section{References}

Chu DKW, Leung CYH, Gilbert M, Joyner PH, Ng EM, Tse TM, Guan Y, Peiris JS, Poon LL (2011) Avian coronavirus in wild aquatic birds. J Virol 85:12815-12820. doi:10.1128/JVI.0583811

Eriksson KK, Cervantes-Barraga L, Ludewig B, Thiel V (2008) Mouse hepatitis virus liver pathology is dependent on ADPribose-1-phosphatase, a viral function conserved in the alphalike supergroup. J Virol 82:12325-12334. doi:10.1128/JVI. 02082-08

Hu H, Jung K, Vlasova AN, Chepngeno J, Lu Z, Wang Q, Saif LJ (2015) Isolation and characterization of porcine deltacoronavirus from pigs with diarrhea in the United States. J Clin Microbiol 53:1537-1548. doi:10.1128/JCM.00031-15

Ma Y, Zhang Y, Liang X, Lou F, Oglesbee M, Krakowka S, Li J (2015) Origin, evolution, and virulence of porcine deltacoronaviruses in the United States. mBio 6:e0064-15. doi:10.1128/ mBio.00064-15

Mihindukulasuriya KA, Wu G, St Leger J, Nordhausen RW, Wang D (2008) Identification of a novel coronavirus from a beluga whale by using a panviral microarray. J Virol 82:5084-5088. doi:10. 1128/JVI.02722-07

Price MN, Dehal PS, Arkin AP (2010) FastTree 2-approximately maximum-likelihood trees for large alignments. PLoS One 5:e9490. doi:10.1371/journal.pone.0009490

Wang L, Byrum B, Zhang Y (2014) Porcine coronavirus HKU15 detected in 9 US States, 2014. Emerg Infect Dis 20:1594-1595. doi:10.3201/eid2009.140756

Woo PCY, Huang Y, Lau SKP, Yuen KY (2010) Coronavirus genomics and bioinformatics analysis. Viruses 2:1804-1820. doi:10.3390/v2081803

Woo PCY, Lau SKP, Lam CSF, Lau CCY, Tsang AKL, Lau JHN, Bai R, Teng JL, Tsang CC, Wang M, Zheng BJ, Chan KH, Yuen KY (2011) Discovery of seven novel Mammalian and avian coronaviruses in the genus deltacoronavirus supports bat coronaviruses as the gene source of alphacoronavirus and betacoronavirus and avian coronaviruses as the gene source of gammacoronavirus and deltacoronavirus. J Virol 86:3995-4008. doi:10.1128/JVI.06540-11 